Historic, archived document

Do not assume content reflects current scientific knowledge, policies, or practices. 
THE CONTINENTAL DIVIDE IN IDAHO AND MONTANA

Nedavia Bethlahmy

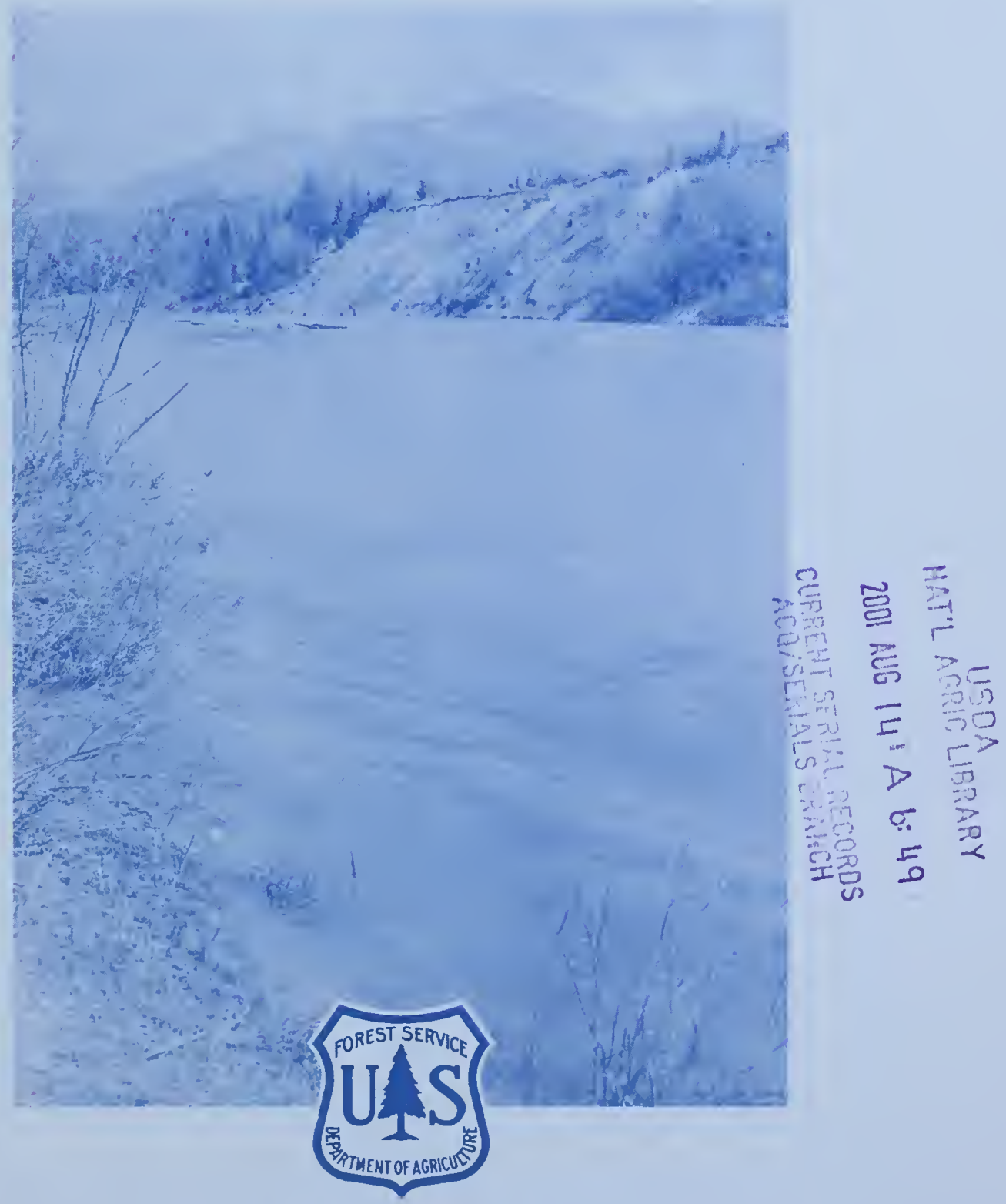

USDA Forest Service Research Paper INT-113 INTERMOUNTAIN FOREST AND RANGE EXPERIMENT STATION Ogden, Utah 84401 



\section{MAXIMUM PEAK FLOWS FOR SELECTED RETURN PERIODS FOR WATERSHEDS WEST OF THE CONTINENTAL DIVIDE IN IDAHO AND MONTANA}

Nedavia Bethlahmy

INTERMOUNTAIN FOREST AND RANGE EXPERIMENT STATION Forest Service

U.S. Department of Agriculture

Ogden, Utah 84401

Robert W. Harris, Director 


\section{THE AUTHOR}

NEDAVIA BETHLAHMY is Principal Forest Hydrologist for the Streamflow Regulation research work unit of the Intermountain Forest and Range Experiment Station in Moscow, Idaho. He began his career with the Forest Service in California in 1940, and since that time has worked and conducted experiments in watershed management research in the Northeastern, Southwestern, Pacific Northwest and Intermountain Regions. During the years 1966-1968, he was assigned to the Food and Agriculture Organization of the United Nations to help the Republic of China solve the watershed management problems of Taiwan. He is a Graduate Forester from Penn State, and holds M.F. and Ph. D. degrees from Yale and Cornell Universities. 


\section{CONTENTS}

Page

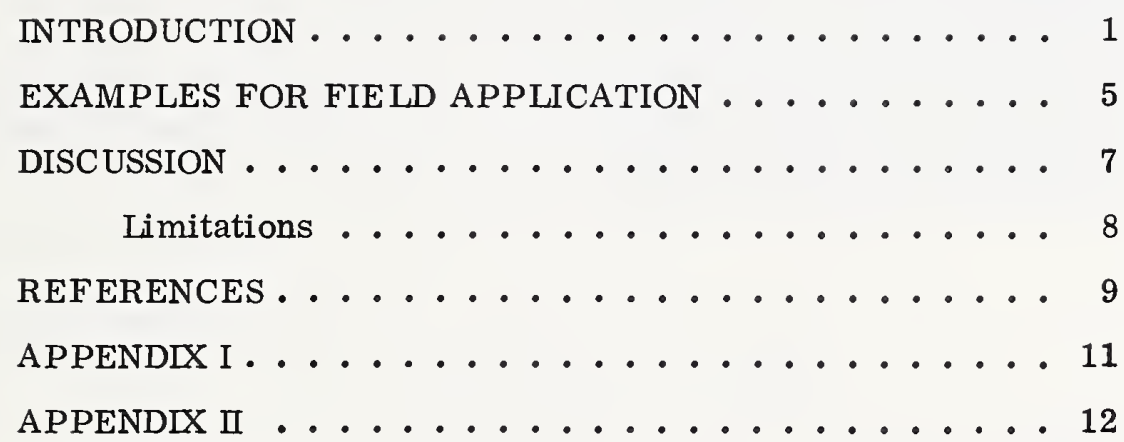




\section{ABSTRACT}

The long-term average water yield of a watershed appears to be a good index to the magnitude of its expected peak flow. On the basis of this relation, tables are presented showing expected peak flows that are applicable to watersheds in Idaho and Montana west of the Continental Divide. Tabulated peak flows are for four different return periods: mean annual; $5 ; 10$; and 20 years. Three examples are given to illustrate the tables' field application. 


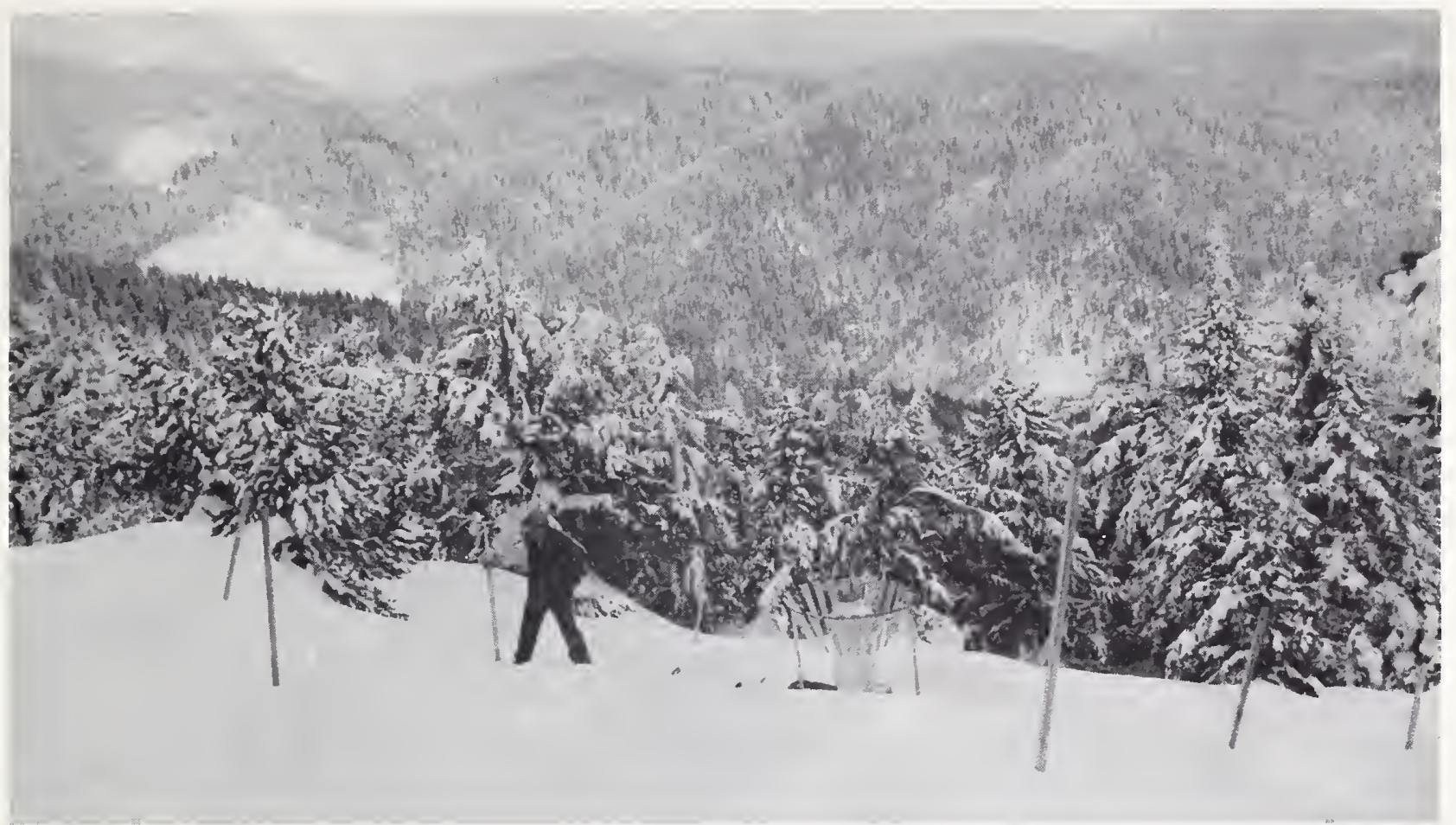

What is the 20-year flood potential of this watershed?

\section{INTRODUCTION}

Foresters and other land managers have long considered water an important product of forest lands. This product yields great benefits when its flow is orderly, timely, and is confined within the banks of a stream. On the other hand, water appearing as a flood is a potentially destructive force that land managers should consider when planning future forest operations.

The effects of clearcutting operations on the hydrologic regime of a watershed are complex, and the magnitude of these effects is highly variable. Nevertheless, we do know that a clearcut watershed yields more water (Hibbert 1967), and that the pattern of runoff distribution is changed, including an increase in base flow and peak flow (Bethlahmy 1971). Thus, foresters and other land managers who contemplate clearcutting operations should consider the associated problem of future changes in the hydrologic regime.

Our research has shown that on a unit area basis the long-term average water yield of a watershed is a good index to the magnitude of its expected peak flow. The greater the average yield per unit area, the greater the expected peak flow for period of record. This relation is readily perceived from table 1 that shows data for 11 rivers in Idaho which have good or excellent streamflow records (U.S. Department of Interior 1964). Notice the regular decrease in values of both average annual flow and associated peak flow. Although peak flow per unit area is related to unit drainage yield, any discussion of peak flow should inciude the element of chance. A record of many years of data will probably include. greater peak flow values than a short record. Hence, a comparison of peak flows for different areas should be based not only on the watershed's average yields but also on the element of time; how long is the record, and how often can one expect a peak flow of a given magnitude? Such considerations are especially important to engineers and economists who are concerned with investments in structures having an economic life expectancy. 
Table 1.--Relation of peak flow to average annual flow for some Idaho rivers with good or excellent stream records

\begin{tabular}{|c|c|c|c|c|c|}
\hline River & $\begin{array}{c}\text { Average } \\
\text { annual } \\
\text { flow } \\
\end{array}$ & $\begin{array}{ll}\text { Peak } & : \\
\text { flow } & \text { : } \\
\end{array}$ & $\begin{array}{c}\text { Elevation } \\
\text { of gage }\end{array}$ & $\begin{array}{l}: \\
: \text { Length } \\
: \text { of record } \\
\end{array}$ & $\begin{array}{cc}: & \\
: & \text { Watershed } \\
: & \text { area } \\
\end{array}$ \\
\hline & ${ }^{2}$ C.f.s.m. & ${ }^{2}$ C.f.s.m. & ${ }^{3}$ Feet & Years & $S q \cdot m i$. \\
\hline Cub & 4.24 & 36.86 & 5,320 & 21 & 19.4 \\
\hline Boundary & 1.98 & 33.81 & 1,770 & 34 & 97 \\
\hline Mission & 1.71 & 22.96 & 2,800 & 6 & 23 \\
\hline Clearwater (Kamiah) & 1.68 & 21.24 & 1,162 & 54 & 4,850 \\
\hline Moyie (Eastport) & 1.23 & 18.60 & 2,620 & 35 & 570 \\
\hline Yaak & 1.20 & 15.80 & 1,850 & 8 & 766 \\
\hline Moyie (Eileen) & 1.16 & 14.57 & 2,124 & 39 & 755 \\
\hline Big Lost River (Wild Horse) & .86 & 11.14 & 6,820 & 20 & 114 \\
\hline Robie & .50 & 10.32 & 4,960 & 14 & 15.8 \\
\hline Thomas Fork & .44 & 7.69 & 6,280 & 15 & 113 \\
\hline Bannock & .36 & 5.91 & 5,240 & 16 & 5.75 \\
\hline
\end{tabular}

${ }^{1}$ Peak flow for period of record.

${ }^{2}$ Cubic feet per second per square mile.

${ }^{3}$ Above mean sea level.

Peak flows which can be expected in Idaho and Montana, in watersheds west of the Continental Divide, are listed in tables 2 and 3 for four different return periods. The selected return periods are: 2.33 years (usually termed the mean annual return period); $5 ; 10$; and 20 years. In these tables, peak flow is a function of average water yield and an expected return period, and is expressed in units of cubic feet per second per square mile (c.f.s.m.). In table 2, average water yield (the independent variable) increases by selected increments in inches, and in table 3 by selected increments in c.f.s.m. These tables were constructed in accordance with the methods described in Appendix 1, and are based on sources of data listed in Appendix 2. 
Table 2.--Maximum peak flows (c.f.s.m.) for selected return periods for watersheds west of the Continental Divide in Idaho and Montana

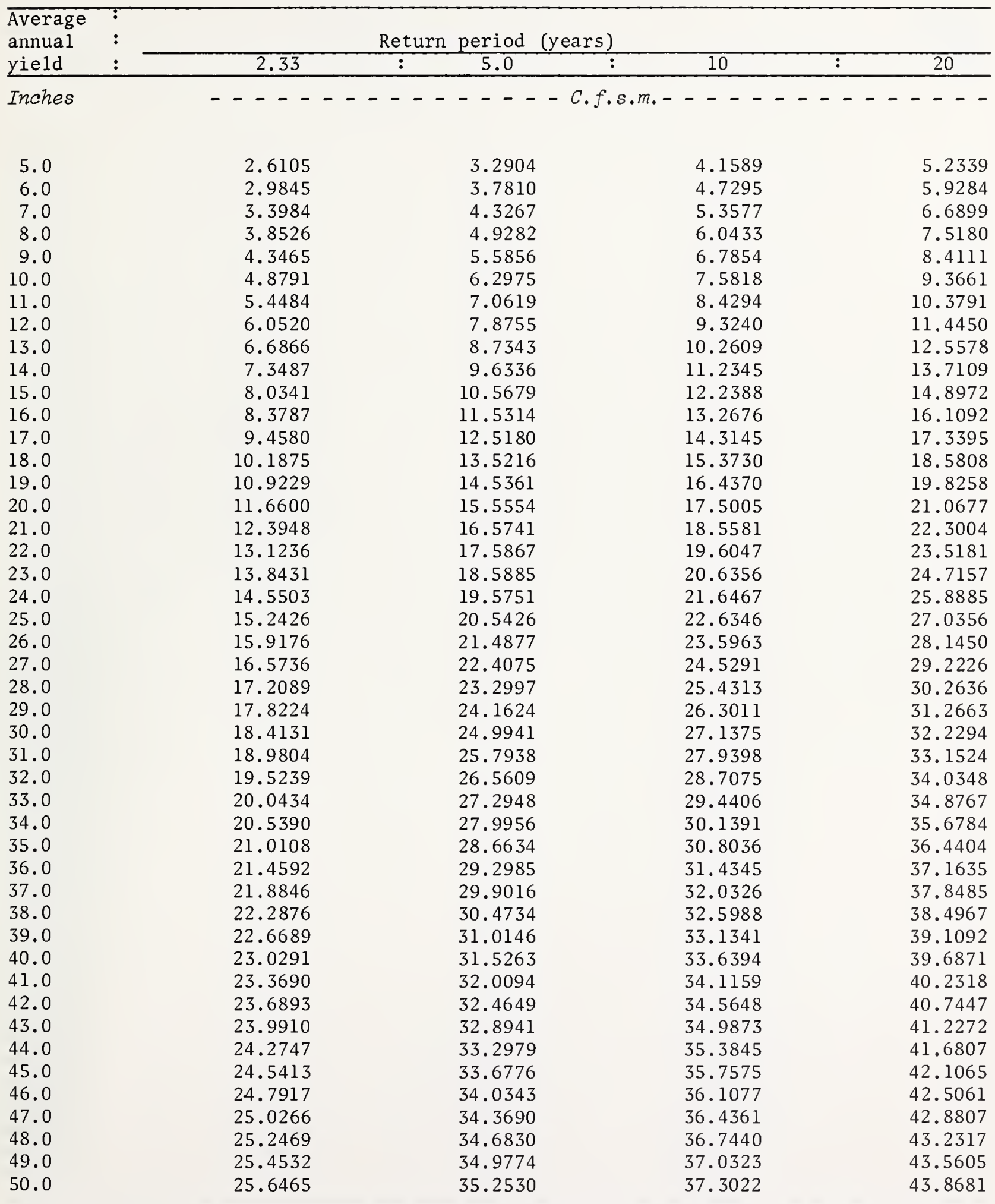


Table 3.--Maximum peak flows (c.f.s.m.) for selected return periods for watersheds west of the Continental Divide in Idaho and Montana

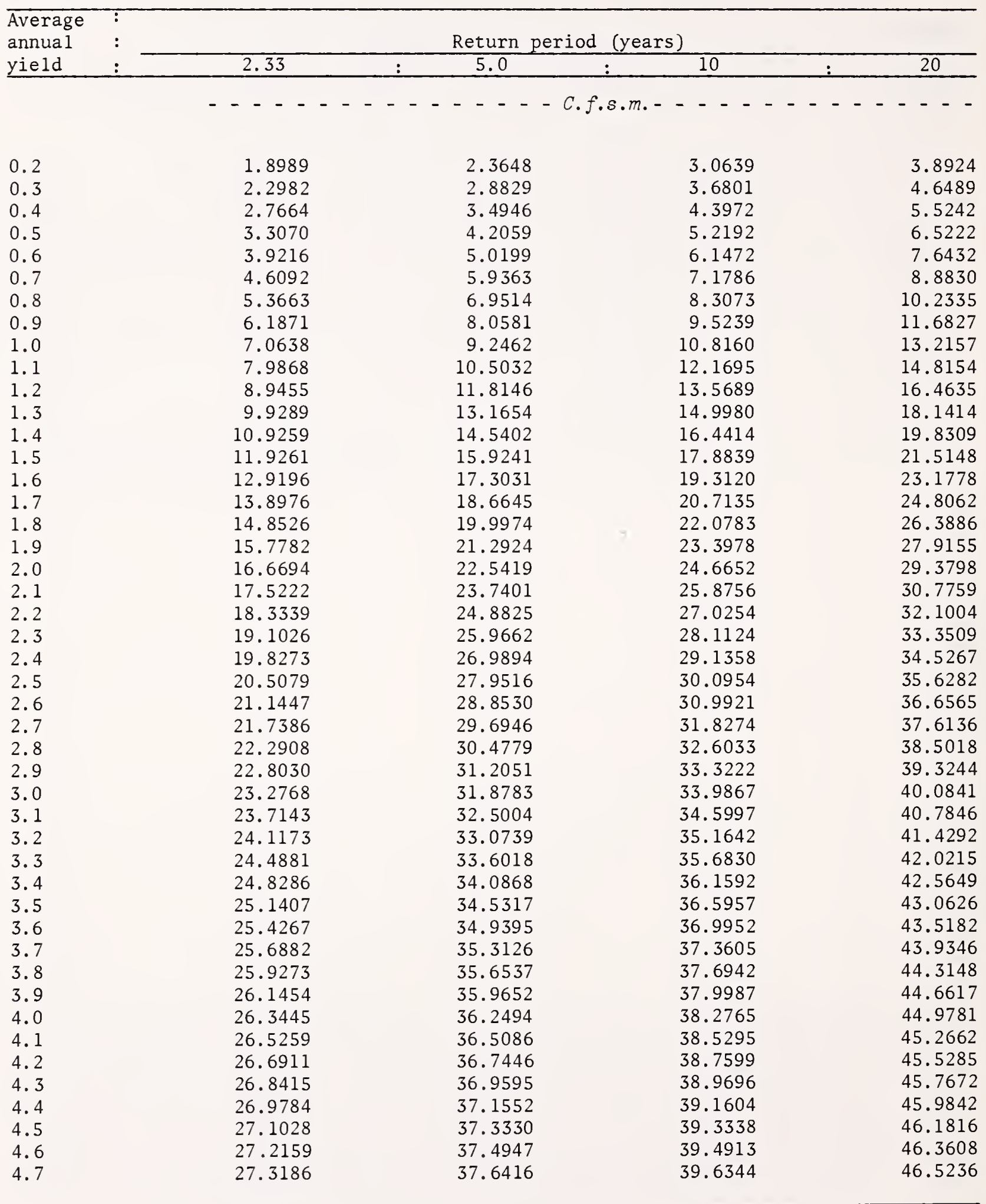



' 



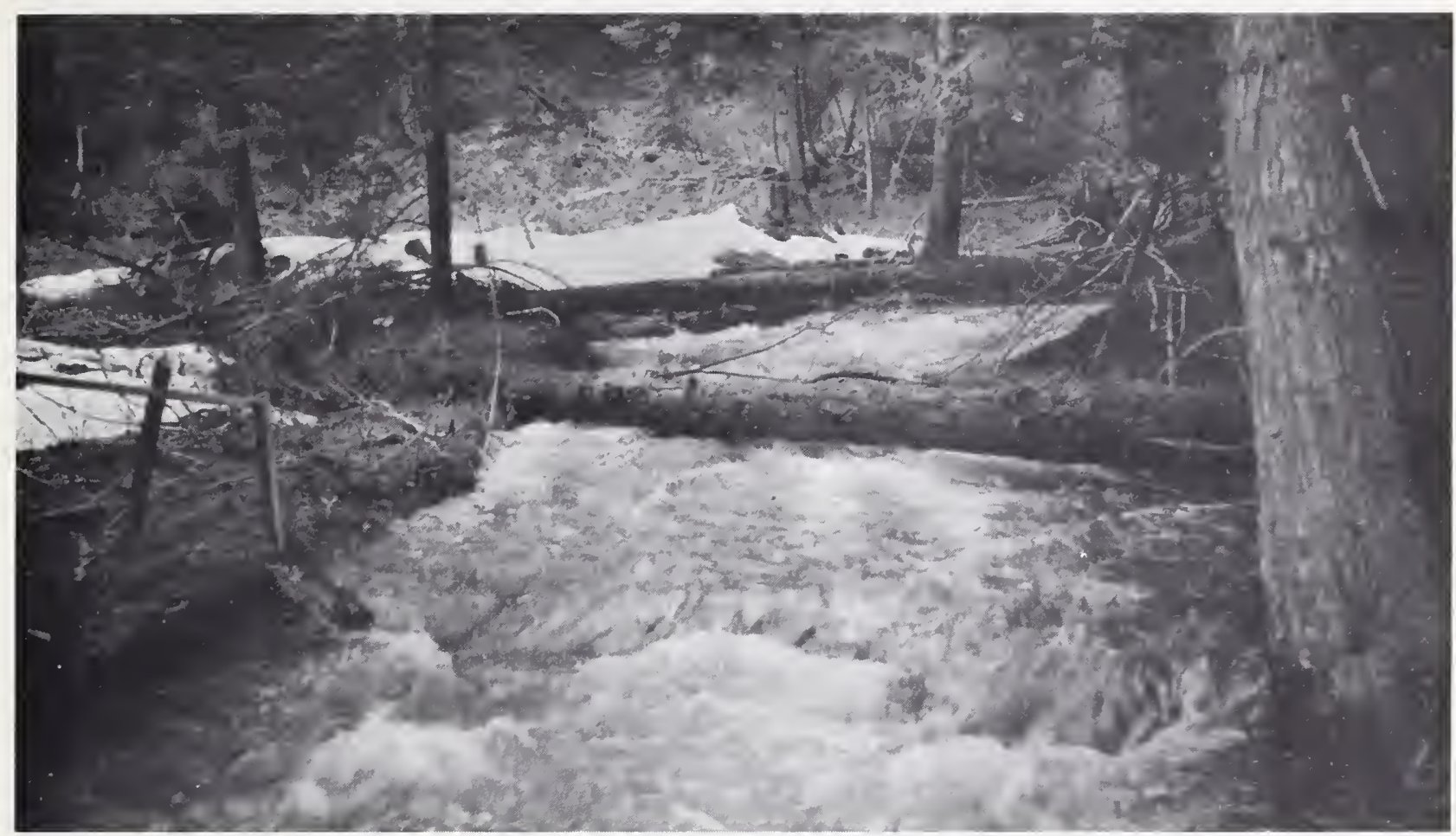

A mountain stream at flood stage.

\section{EXAMPLES FOR FIELD APPLICATION}

Three examples are given to show how the tables can be used for field application. EXAMPLE 1

Problem: A road will be built across the outlet of a 1.5-sq.-mi. drainage having an expected annual water yield of 40 inches. What is the maximum rate of flow the culvert should accommodate:

(a) if designed for a 20-year flood?

(b) if designed for a 50-year flood?

Solution:

(a) For an annual yield of 40 inches, table 2, col. 5, shows a peak flow of 39.69 c.f.s.m. Since the drainage area is 1.5 sq. mi., we can expect a 20 -year flood of 59.53 c.f.s. $(39.69 \times 1.5)$.

(b) The tables do not show peak flows for return periods exceeding 20 years. Extrapolation is required, but this procedure is fraught with great uncertainty. In table 2, opposite an average 40-inch annual yield, we find the expected peak flows for the 10 - and 20 -year floods to be 33.64 and 39.69 c.f.s.m., respectively. Plot the paired values (year versus flow) on log-log paper, connect them with a straight line, and extend the line to the 50 -year flood. The peak flow is 49.3 c.f.s.m. Inasmuch as the area is $1.5 \mathrm{sq}$. mi., the expected 50 -year flood is $74 \mathrm{c.f} . \mathrm{s} .(49.3 \times 1.5=74)$.

It must be understood that such extrapolation results in only approximate values. 


\section{EXAMPLE 2}

Problem: A road crosses the outlet of a 40-acre watershed over a 12-inch corrugated metal culvert whose top is 1 foot below the road surface. Plans call for clearcutting the watershed that has an annual yield of 35 inches. After cutting we expect annual water yield to increase by 15 percent. Assuming a 20-year-design flood, will the presently located culvert accommodate the increased flow?

\section{Solution:}

The expected annual flow is 40.25 inches (35 inches $X 1.15$ ). In table 2, col. 5, interpolating for peak values between 40 and 41 inches, we obtain an expected peak flow of 39.82 c.f.s.m. Since the area involved is 40 acres, the expected peak flow is 2.49 c.f.s. $\left(39.82 \times \frac{40}{640}\right)$. Using culvert discharge tables (e.g., Hendrickson 1957), we find that the presently installed culvert (use 1.0 percent slope and 0.025 roughness coefficient) will accommodate only 2.4 c.f.s. Because there is a present capacity of only 2.4 c.f.s., and the expected need is for 2.49 c.f.s., it appears that the road will probably be damaged by overflowing unless a larger culvert is installed or the surface of the road is raised to allow for ponding.

\section{EXAMPLE 3}

Problem: The annual water yield from a 5.0-sq.-mi. drainage is 40 inches. Plans call for clearcutting a 40-acre subwatershed. What are the present and expected peak flows at the outlet of the main drainage for a 10-year flood if the annual water yield of the clearcut area is expected to increase by 15 percent?

\section{Solution:}

Under present conditions (before cutting) the expected 10-year flood for the entire drainage is $168.20 \mathrm{c.f.s}$. In table 2, col. 4, opposite 40 inches, read 33.64 c.f.s.m. and multiply by $5.0 \mathrm{sq}$. mi., and for the 40 -acre subwatershed it is $2.10 \mathrm{c} . \mathrm{f} . \mathrm{s}$. $\left(33.64 \times \frac{40}{640}\right)$.

After cutting, the average yield from the clearcut 40-acre subwatershed will be 46.0 inches $(40 \times 1.15)$. In table 2 , col. 4, we read a peak flow value of 36.11 c.f.s.m. Since the subwatershed is 40 acres, the peak flow is 2.26 c.f.s. $\left(36.11 \times \frac{40}{640}\right)$.

On the clearcut area, the peak flow will increase by 0.16 c.f.s. $(2.26-2.10)$. Add this value to the precutting peak flow for the entire drainage:

$$
168.20+0.16=168.36 \text { c.f.s. }
$$

It is apparent that clearcutting the 40 -acre subwatershed will not alter the peak flow of the main watershed in any significant way. 


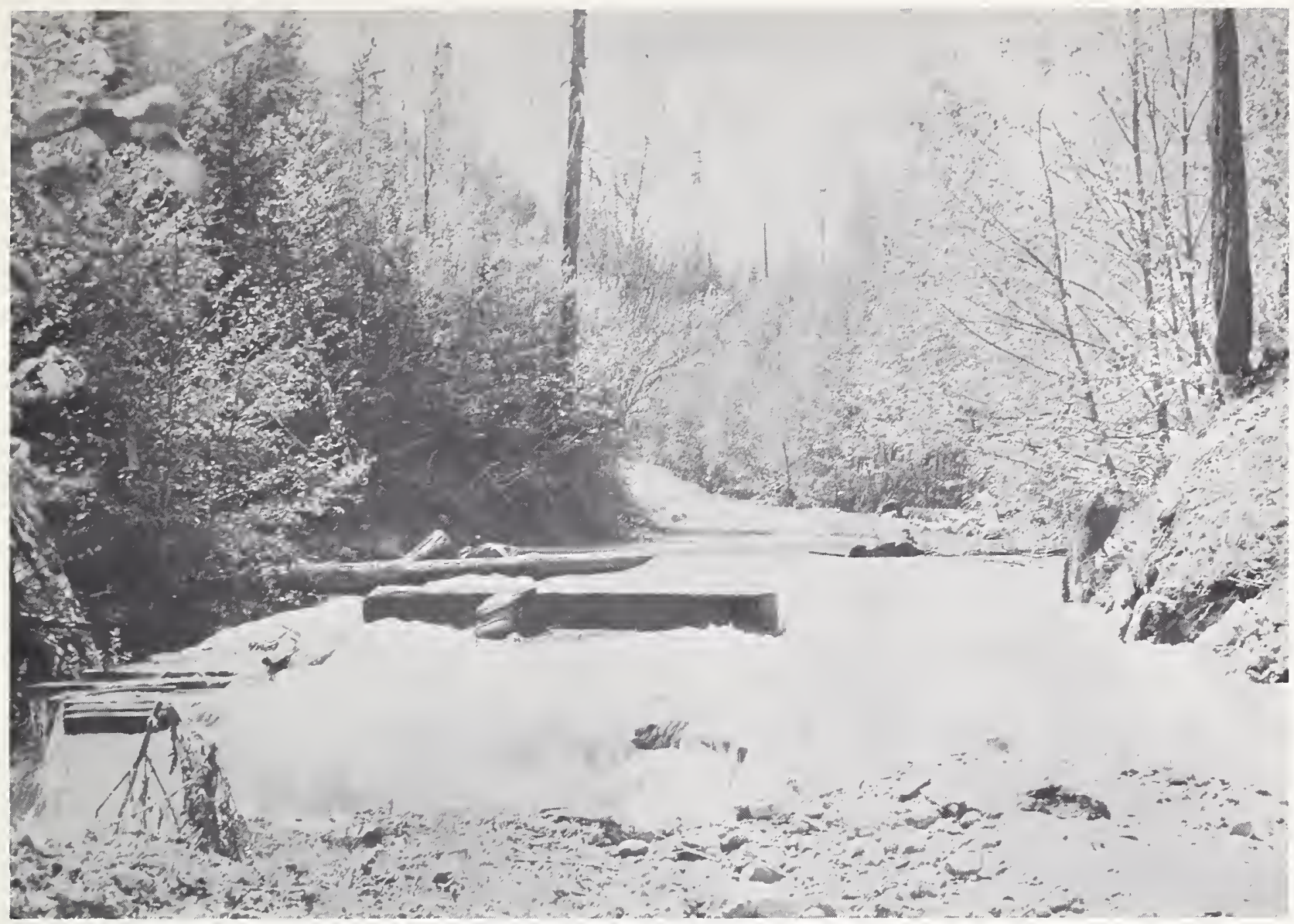

A raging mountain stream overflows a bridge.

\section{DISCUSSION}

The three examples illustrate how the tables may be used, and the practical significance of the effects of clearcutting operations. We once again remind the reader that the tabulated values are expressed in yield per unit area, and hence may be applied to watersheds of any size or at any elevation.

In illustrating the use of the tables, we used a potential water yield increase of 15 percent. Some readers may consider this figure as too conservative, because it is considerably smaller than figures reported in the literature. At Fraser, Colorado, for example, where 75 percent of the annual precipitation occurs as snow, a 40 -percent commercial clearcut in strips yielded a first-year increase of 30 percent in annual streamflow (Goodell 1958). We used the figure 15 percent as an example, and not as a universal recommendation. In using the tables, the reader should consider the special circumstances applying to his case.

The tables may also be used to solve problems relating to channel stability, bank cutting, and stream level. However, because the characteristics of stream channels vary considerably from one segment to another, it is apparent that a particular problem may not have a unique solution. Nevertheless, the land manager may sometimes be particularly concerned with certain segments of a stream channel because they appear vulnerable to changes in the hydrologic regime. In such cases, it may be worthwhile to make the assumptions needed to perform the calculations and to determine the magnitude of changes that can be expected. 


\section{Limitations}

Flood peaks reflect the complex interaction of many variables, and many formulas have been devised to account for the effects of these variables. In most cases, however, the land manager has only limited information about the magnitude of the important variables. For example, Rosa (1968) published water yield maps for Idaho, but maps of this sort are not available for even such basic variables as rainfall intensity or soils grouped according to their hydrologic properties.

The user of these tables is cautioned that the tabulated values are far from being definitive; they are only an approximation to give the land manager an idea of what may be expected. Mr. C. A. Thomas has observed that the tabulated values may be too high for streams with a high base flow and are probably too low for streams with flashy runoff and low base flows.

The user should bear in mind that the tables will probably be applied to areas considerably smaller than those from which the tables were derived. Furthermore, flow data for the very small drainages cover only a brief span of time.

${ }^{1}$ Personal communication, on file at Intermountain Forest and Range Experiment Station, Forestry Sciences Laboratory, Moscow, Idaho. 


\section{REFERENCES}

\section{Bethlahmy, Nedavia}

1971. Effects of forest clearfelling on the storm hydrograph--a reanalysis. Amer. Geophys. Union Trans. 52(4): 204.

Bodhaine, G. L., and D. M. Thomas

1964. Magnitude and frequency of floods in the United States. Part 12. Pacific Slope Basins in Washington and Upper Columbia River Basin. Geol. Surv. Water-Supply Pap. 1687.

Goode11, B. C.

1958. A preliminary report on the first year's effects of timber harvesting on water yields from a Colorado watershed. USDA Forest Serv., Rocky Mountain Forest Exp. Sta. Res. Pap. 36, 12 p.

Hendrickson, John G., Jr.

1957. Hydraulics of culverts. Chicago, I11.: Amer. Concrete Pipe Assoc.

Hibbert, Alden R.

1967. Forest treatment effects on water yield. P. 527-543, in: William E. Sopper, and Howard Lull (eds.), Forest Hydrology. Pergamon Press.

Rosa, J. Marvin

1968. Water yield maps for Idaho. USDA Agr. Res. Serv. 41-141.

Thomas, C. A., H. C. Broom, and J. E. Cummans

1963. Magnitude and frequency of floods in the United States. Part 13. Snake River Basin. Geol. Surv. Water-Supply Pap. 1688.

U.S. Department of Interior

1964. Surface water records of Idaho. USDI Geol. Surv., 281 p. 



\section{APPENDIX I}

The published tables are based on the finding that peak flow is a function of mean water yield. The equation is:

$$
\ln (P / A)=a+b[1.5708-\operatorname{arc} \tan (\sinh F / A)]
$$

in which $P, A$, and $F$ are, respectively, peak flow (c.f.s.), area (square miles), and mean flow (c.f.s.). The constant 1.5708 is the angle $90^{\circ}$ expressed in radians.

Equation (1) is based on data found in Thomas, Broom, and Cummans (1963) and Bodhaine and Thomas (1964). Only those rivers were analyzed whose records indicated no diversions, impoundments, or poor data. The equation was derived as follows: For each streamflow record, the annual peak flow data were arranged in a descending order of magnitude. If $N$ represents the total number of items in the series, and $M_{i}$ is the ordered position in the series (i.e., $1,2 \ldots M_{i} \ldots . N$ ), then the probability of occurrence $\left(P_{r}\right)$ (or percent chance) for a peak flow equal to or smaller than that in ordered position $M_{i}$ is

$$
100 \times \frac{\left(M_{i}-0.5\right)}{N}
$$

This probability was calculated for each ordered position, and defined the plotting position of the associated peak flow on log-normal paper. A smooth line was drawn through the plotted data, but was not extended beyond the range of the plotted data. We then read the adjusted peak flows for the selected recurrence periods: $2.33 ; 5 ; 10$; and 20 years. (The recurrence period is 100 divided by the probability of occurrence; e.g., if $P_{r}=20, T_{r}=5$. )

Data drawn from the smooth curves formed four new sets of data, one for each selected recurrence period. Each set of data was then analyzed to obtain the values of $a$ and $b$ in equation (1). We have listed below these values, as well as the correlation coefficient $(R)$ relating the dependent and independent variables.

$\begin{array}{cccc}\begin{array}{c}\text { Recurrence period } \\ \text { (Years) }\end{array} & a & b & R \\ 2.33 & & & \\ 5 & 3.3434 & -1.9693 & 0.966 \\ 10 & 3.6653 & -2.0440 & .950 \\ 20 & 3.7141 & -1.8908 & .938 \\ & 3.8733 & -1.8324 & .902\end{array}$

Values for tables 1 and 2 were calculated for selected values of mean flow (F/A) using the equation

$$
\frac{P}{A}=\mathrm{e}^{a+b\left[1.5708-\operatorname{arc} \tan \left(\sinh \frac{F}{A}\right)\right]}
$$

where e is 2.71828 , base for Naperian logarithms. 


\section{APPENDIX II}

Data for the following rivers were used to derive equation 1 .

River No. (USGS)
River name and location

Length of record

$\underline{\text { Area }}$

Years

$S q \cdot m i$.
Mean

elevation

Feet

IDAHO

$12-3055$

$12-3065$

$12-3075$

$12-4110$

$12-4130$

$13-3170$

$13-3375$

$13-3390$

13-3405

$13-1200$

$13-1625$

$13-1850$

$13-1965$

13- 115

$13-320$
Boulder Creek near Leonia

Moyie River at Eastport

Moyie River at Eileen

Coeur d'Alene River near Prichard

Coeur d'Alene River at Enaville

Salmon River at White Bird

South Fork Clearwater River at Elk City

Clearwater River at Kamiah

North Fork Clearwater River at Bungalow Ranger Station

Big Lost River at Wildhorse, near Chilly

East Fork Jarbridge River near

Three Creek

Boise River near Twin Springs

Bannock Creek near Idaho City

WYOMING

37

36

40

14

26

53

21

55

13

21

16

54

17

Bear Creek near Irwin
21

12

$\begin{array}{rr}53 & 4,980 \\ 570 & 4,870 \\ 755 & 4,710 \\ 335 & 4,120 \\ 895 & 3,610 \\ 13,550 & 6,720 \\ 261 & 5,150 \\ 4,850 & 5,010 \\ 996 & 4,930 \\ 114 & 8,540 \\ 89 & 7,600 \\ 830 & 6,350 \\ 5.75 & 5,240\end{array}$

160

8,160

$77.1 \quad 7,130$

MONTANA
3505

3560

3585
Kootenai Creek near Stevensville

Skyland Creek near Essex

Middle Fork Flathead River near West Glacier

South Fork Flathead River at Spotted Bear

Spotted Bear River near Hungry Horse

Twin Creek near Hungry Horse

Sullivan Creek near Hungry Horse

Graves Creek near Hungry Horse
7

6

18

10

8

8

9

9

$$
\begin{array}{cc}
28.9 & 6,670 \\
8.09 & 5,920
\end{array}
$$

8

8

1,128

958

184

47

71.3

5,800

6,130

5,960

5,300

5,510

$27 \quad 5,430$ 
Headquarters for the Intermountain Forest and Range Experiment Station are in Ogden, Utah. Field Research Work Units are maintained in:

Boise, Idaho

Bozeman, Montana (in cooperation with Montana State University)

Logan, Utah (in cooperation with Utah State University)

Missoula, Montana (in cooperation with University of Montana)

Moscow, Idaho (in cooperation with the University of Idaho)

Provo, Utah (in cooperation with Brigham Young University) 
